\title{
Çilekte Kök ve Taç Çürüklüğü Hastalığı (Phytophthora cactorum)’na Karşı Kök Bakterileri ile Biyolojik Mücadele
}

\section{Ümit ÖZYILMAZ ${ }^{* 1}$ (I) Kemal BENLIOĞLU ${ }^{1}$}

\author{
${ }^{1}$ Aydın Adnan Menderes Üniversitesi, Ziraat Fakültesi, Bitki Koruma Bölümü, AYDIN
}

Öz: Phytophthora kök ve taç çürüklüğü (Phytophthora cactorum) çilek üretimini sınırlayan hastalıklardan bir tanesidir. Bu çalışma hastalık ile mücadelede antagonist bakterilerin kullanılmasını hedeflemektedir. Bu amaçla; çilek, karnabahar, kırmızı lahana, brokoli, lahana, turp, bakla ile yabancı otlardan yabani turp, darıcan ve çoban çantası bitkilerinin kök bölgesinden toplam 362 adet bakteri izole edilmiştir. Yapılan ikili kültür ve bazı ön eleme testleri ile çalışılan bakteri sayısı 101'e daha sonra da 24 düşürülmüştür. Bu antagonistlerin sahip oldukları etki mekanizmalarını belirlenmeye yönelik testlerde; hiç bir izolatın kitinaz, selülaz ve pektinaz aktivitesine sahip olmadığı, 13 izolatın proteaz, 3 izolatın fosfataz aktivitesine sahip olduğu, 20 izolatın inorganik fosfatı çözebildiği saptanmıştır. 19 izolatın HCN, 18 izolatın siderofor, 11 izolatın yüzey aktif madde ve 16 izolatın da 2-4,DAPG ürettiği bulunmuştur. Antagonistlerin IAA üretim kabiliyetlerine bakııdığında 62.4 ve 1.9 $\mathrm{\mu g} / \mathrm{ml}$ olarak iki izolatın IAA ürettiği belirlenmiştir. Tüm bakteriler Pseudomonas spp. olarak tanılanmıştır. Saksı denemelerinde 3ss9 ve 6110 izolatlarının P. cactorum'a karşı \%50 oranında bir engelleme gösterdiği bulunmuştur.

Anahtar Kelimeler: Phytophthora, antagonist, kök bakterileri, Pseudomonas

Biological Control of Root and Crown Rot Disease of Strawberry (Phytophthora cactorum) with Rhizobacteria

\begin{abstract}
Phytophthora Root and Crown Rot (Phytophthora cactorum) is one of the diseases of strawberry that limit production. This study aims to use antagonistic bacteria against the disease. For this purpose, a total of 362 bacteria were isolated from the rhizosphere of strawberry, cauliflower, red cabbage, broccoli, cabbage, radish, wild radish, broad bean, barnyard grass, and shepherd's purse plants. The number of bacteria studied was reduced to 101 and then to 24 according to dual culture and pre-tests. In tests to determine the mode of actions of these antagonists; out of 24 bacteria, none of the isolates produced chitinase, cellulase, and pectinase, while 13 produced protease, 19 produced HCN, 18 produced siderophore, 11 produced biosurfactant, 16 produced 2-4 DAPG, 2 produced IAA (62.4 ve 1.9 $\mu \mathrm{g} / \mathrm{ml})$. Three antagonists had a phosphatase activity. Twenty had able to solubilize inorganic phosphorus. All bacteria were identified as Pseudomonas spp. $3 s s 9$ and 6110 reduced the disease severity by \%50 in pots trials.
\end{abstract}

Keywords: Phytophthora, antagonist, rhizobacteria, Pseudomonas

\section{GiRiş}

Çileğin (Fragaria $\times$ ananassa Duch.) bitki koruma açısından birçok problemi bulunmaktadır. Bunlar içinde belki de en önemli olanlarından biri toprak kaynaklı patojenlerdir. Bu patojenler Rhizoctonia solani, Fusarium oxysporum, Verticillium dahliae, Phytophthora cactorum, Pythium spp., Phoma spp., Colletotrichum spp. ve Macrophomina phaseolina olarak belirlenmiştir (Benlioğlu ve ark., 2018; Maas, 1998; De los Santos ve ark., 2003; Golzar ve ark., 2007). Aydın ili Sultanhisar ilçesinde yetiştirilen çileklerde 1997-2000 yılları arasında Rhizoctonia solani ve Phytophthora cactorum'un öne çıkan patojenler olduğu rapor edilmiştir (Benlioğlu ve ark., 2004).

Toprak patojenlerine ve yabancı otlara karşı kullanılan metil bromürün yasaklanmasının ardından, çilek üretiminde solarizasyon çevre dostu ve iyi bir alternatif olarak öne çıkmıştır (Benlioğlu ve ark., 2005). Gerek fümigasyon gerekse solarizasyon sonunda topraktaki mikroorganizmalar ölmekte ve rekabet ortamı ortadan kalkmaktadır. Bu durumda bazı mikroorganizmaların sayısı diğerlerine göre artmaktadır. Örneğin fumigasyon uygulanmış topraklarda bitki köklerinde toplam fluoresan Pseudomonas'ların sayısının arttığı bildirilmiştir (Martin ve Bull, 2002). Farklı bitkilerde çeşitli patojenlere karşı yapılan biyolojik savaş araştırmalarında Pseudomonas'ların iyi birer bakteriyel antagonist ya da bitki gelişimini arttıran bakteri (PGPR) oldukları birçok çalışmada belirtilmiştir (Gamliel ve Katan, 1993; Koch ve ark., 1998; Gulati ve ark., 1999; De La Fuente ve ark., 2000; Berg ve ark., 2000a; Berg ve ark., 2001).

Çileğin önemli problemlerinden biri olan Phytophthora cactorum dünyanın birçok bölgesinde çilek üretimini etkilemektedir. Fideler yardımıyla farklı lokasyonlara taşınabilen hastalık drenaj ve sulama suları ile kolaylıkla yayılabilmektedir (Eikemo ve ark., 2000; 2003). Kök ve taç çürüklüğüne neden olan hastalık aynı zamanda derimsi meyve çürüklüğüne de sebep olmaktadır (Irzykowska ve ark., 2005).

Sorumlu Yazar: uozyilmaz@adu.edu.tr Bu çalışma ilk yazarın doktora çalışmasının bir bölümüdür. Çalışmanın bir kısmı Türkiye IV. Bitki Koruma Kongresinde (28-30 Haziran 2011) sunulmuş ve özet metni basılmıştır. Çalışma Tübitak TOVAK-TOGTAG 103 O 146 nolu proje ile desteklenmiştir.

Geliş Tarihi: 1Şubat 2019

Kabul Tarihi: 25 Haziran 2019 
Bu çalışma; Phytophthora cactorum'a karşı etkili olabilecek antagonist Pseudomonas'ları bazı bitkilerin köklerinden izole etmek, bu antagonistlerin etki mekanizmalarını belirlemek ve gerek in-vitro gerekse iklim odası çalışmaları ile antagonizmi ortaya koymak amacıyla yürütülmüştür.

\section{MATERYAL ve YÖNTEM}

\section{Antagonist Bakteri İzolasyonu ve Ön Testler}

Çalışmada kullanılacak antagonist bakteriler Aydın ili Sultanhisar ilçesinde, 2003 yılı Şubat, Nisan, Kasım ve 2004 yılı Nisan, Ağustos, Eylül aylarında, çilek bitkileri (Camarosa ve Sweet Charlie çeşidi) ile aynı yörede çilek ekim alanlarında yetiştirilen Crucifereae familyası sebzeleri karnabahar (Brassica oleracea L. var. botrytis), kırmızı lahana (Brassica oleracea L. var. rubra), brokoli (Brassica oleracea L. var. italica), lahana (Brassica oleracea L. var. capitata), turp (Raphanus sp.) bitkilerinden, ayrıca bakla (Vicia faba) bitkileri ile yabani turp (Raphanus raphanistrum L.), darıcan (Echinochloa crus-galli L.) ve çoban çantası (Capsella bursa-pastoris (L.) Medik.) yabancı otlarının köklerinden izole edilmiştir. Çalışmalarda kullanılan 11 adet tanısı yapılmış $P$. cactorum çilek izolatı Adnan Menderes Üniversitesi, Ziraat Fakültesi Bitki Koruma Bölümü stok kültürlerinden sağlanmıştır. Saksı koşullarında yapılan hastalık etmeni virülenslik belirleme testleri ve biyolojik etkinlik testleri; 16 saat aydınlık / 8 saat karanlık döngülü, $24 \pm 1^{\circ} \mathrm{C}^{\prime}$ ye ayarlı iklim odasında, çalışma sırasında bölgede yaygın ekimi yapılan hastalığa orta duyarlılıktaki (Browne ve ark., 2003) Camarosa çeşidi frigo fideleri kullanılarak yapılmıştır.

Antagonist bakterilerin bitki köklerinden izolasyonu için $3 \mathrm{~g}$ kök örneği $27 \mathrm{ml}$ steril fizyolojik serum (\%0.85 NaCl, pH7.0) içinde stomacher (BagMixer ${ }^{\oplus}$, Interscience, Fransa) ile homojenize edilmiştir (Berg ve ark., 2001). Hazırlanan seyreltme serilerinden King B (King ve ark., 1954) besiyerlerine ekim yapılmış ve $25^{\circ} \mathrm{C}^{\prime}$ de 4 gün gelişme sonunda farklı koloni morfolojisine sahip koloniler saflaştırılmıştır. Ayrıca King B besiyerinde UV ışık altında fluoresans verme durumları kaydedilmiştir. Saflaştırılan her bakteri izolatı $P$. cactorum (P2/01) ile PDA besi yerinde karşılıklı ekilerek, potansiyel antimikrobiyal etkisi olanlar ikili kültürde oluşan engelleme zonunun ölçüm yapılmaksızın değerlendirilmesi ile belirlenmiş ve $-80^{\circ} \mathrm{C}^{\prime}$ ye yedeklenmiştir.

İkili kültür ön eleme testleri ile sayıları azaltılan antagonist adaylarının detaylı ikili kültür testleri üç tekerrürlü olarak petri kabında Bora ve Özaktan (1998)'nın önerdiği yönteme ufak eklemeler yapılarak gerçekleştirilmiş ve engelleme zonları ölçülmüştür. Bunun için; PDA besiyerinin $(\mathrm{pH} 7)$ merkezinden $25 \mathrm{~mm}$ uzaklıktaki 4 farklı noktaya $5 \mu \mathrm{l} 10^{8}$ hücre/ml bakteri süspansiyonu damlatılmış ve 24 saat sonra merkeze $10 \mathrm{~mm}$ çaplı $P$. cactorum (P2/01) diski yerleştirilmiştir. Değerlendirme bakteri uygulaması yapılmayan kontrol petrilerindeki miseliyal gelişimin merkezden $25 \mathrm{~mm}$ mesafeye ulaşmasıyla birlikte engelleme zonlarının ölçülmesi şeklinde yapılmıştır.

Çalışma kapsamında değerlendirilmeyecek bakteri izolatlarının belirlenmesi için bazı testler yapılmıştır. Bunun için; bitkilerde oluşabilecek bir duyarlılığın belirlenmesi için tütünde aşırı duyarlılık testleri (Klement, 1963), çilek fide dikim uygulaması sırasında çevre sıcaklıklarını tolere edemeyecek izolatların belirlenmesi için $37^{\circ} \mathrm{C}^{\prime}$ de gelişme testleri, ayrıca gram boyama testleri yapılmıştır.

\section{Sekonder Metabolit Üretme Kabiliyetleri}

Potansiyel antagonist izolatların in-vitro'da bazı sekonder metabolitleri üretme yetenekleri araştırılmıştır. Tüm testler en az üç tekerrürlü olacak şekilde gerçekleştirilmiştir.

Kitinaz: Kitinaz aktivitesini belirlemek için bakteriler Kitin Agar (CA; 1.62 g Nutrient broth, $0.5 \mathrm{~g} \mathrm{NaCl}, 3.6 \mathrm{~g} \mathrm{Na}{ }_{2} \mathrm{HPO}_{4}$, $1.8 \mathrm{~g} \mathrm{KH}_{2} \mathrm{PO}_{4}, 0.6 \mathrm{~g} \mathrm{NH}_{4} \mathrm{Cl}, 2 \mathrm{~g}$ kitin, $0.1 \mathrm{mM} \mathrm{CaCl}_{2}, 1 \mathrm{mM}$ $\mathrm{MgSO}_{4}, 3 \mathrm{nM}$ Thiamin- $\mathrm{HCl}, 15 \mathrm{~g}$ agar, $1 \mathrm{~L}$ damıtık su, $\mathrm{pH}$ 7.2) besi yerine ekilmiş ve $30^{\circ} \mathrm{C}^{\prime}$ de 5 günlük inkubasyonun sonunda bakterilerin çevresinde oluşan açık alanlar pozitif sonuç olarak kaydedilmiştir (Berg, 1996; Berg ve ark., 2000b).

Proteaz: Proteaz aktivitesini belirlemek için bakteriler skim milk agar besi yerine $(50 \mathrm{ml}$ sterilize edilmiş skim milk, 50 $\mathrm{ml} 1 / 5$ TSA ve $\% 4$ agar) ekilmiştir. 5 günlük $20^{\circ} \mathrm{C}^{\prime} \mathrm{de}$ inkubasyonun sonunda koloniler etrafındaki açık alanlar pozitif sonuç olarak kaydedilmiştir (Krechel ve ark., 2002).

Pektinaz: Pektinaz aktivitesi için pektat agar besiyerinden (4.5 $\mathrm{ml} 1 \mathrm{~N} \mathrm{NaOH}, 3 \mathrm{ml} \% 10 \mathrm{CaCl}_{2} .2 \mathrm{H}_{2} \mathrm{O}, 0.5 \mathrm{ml} \% 1.5$ brothymol blue, $5 \mathrm{~g}$ yeast ekstrakt, $1.5 \mathrm{~g}$ agar, $15 \mathrm{~g}$ sodyum polipektat ve $500 \mathrm{ml} \mathrm{su}$ ) yararlanılmıştır (Beraha, 1968). $25^{\circ} \mathrm{C}^{\prime}$ de 18 saatlik inkubasyonun ardın bakterilerin bir çukur oluşturarak gelişmesi pozitif reaksiyon olarak kaydedilmiştir.

Selülaz: Selülaz aktivitelerinin belirlenmesi için dört ayrı solüsyondan oluşan besiyeri kullanılmıştır (Andro ve ark., 1984). Her biri ayrı ayrı otoklav edilen solüsyonlardan (Solüsyon A: $0.25 \mathrm{~g} \mathrm{NaCl}, 1.5 \mathrm{~g} \mathrm{~K}_{2} \mathrm{HPO}_{4}, 2.5 \mathrm{~g}$ karboksi metil selüloz, $400 \mathrm{ml}$ damıtık su; Solüsyon B: $3 \mathrm{~g} \mathrm{Na}_{2} \mathrm{HPO}_{4}, 0.5 \mathrm{~g}$ $\mathrm{NH}_{4} \mathrm{Cl}, 2.5 \mathrm{~g}$ glycerol, $0.5 \mathrm{~g}$ yeast ekstrakt, $6.5 \mathrm{~g}$ agar $100 \mathrm{ml}$ damıtık su; Solüsyon C: $1 \mathrm{M} \mathrm{MgSO}_{4}$ ve Solüsyon D: \%7.5 v/w $\mathrm{CaCl}_{2}$ ) $A$ ve $B$ karıştırıldıktan sonra $C$ ve $D$ solüsyonlarından $1^{\prime}$ er $\mathrm{ml}$ bu karışımın üzerine eklenmiştir. $25^{\circ} \mathrm{C}^{\prime}$ de 4 gün inkunasyonun sonunda gelişen bakteri kolonilerinin üzerine \%0.1 kongo kırmızısı dökülmüş, $20 \mathrm{dk}$ sonra uzaklaştırılmış, $1 \mathrm{M} \mathrm{NaCl}$ konulmuş ve $5 \mathrm{dk}$ beklenmiştir. Koloniler etrafındaki sarı alanlar pozitif olarak kaydedilmiştir (Andro ve ark., 1984; Klement ve ark., 1990). 
DNAz: Merck DNAz hazır besi yerinden faydalanılan testte $25^{\circ} \mathrm{C}^{\prime}$ de 5 günlük inkubasyonun sonunda bakteri kolonilerinin üzerine $1 \mathrm{~N} \mathrm{HCl}$ dökülmüş ve oluşan açık zon pozitif olarak kaydedimiştir (Jeffries ve ark., 1957). Fosfataz: Holt ve diğerlerinin (1994) önerdiği yöntem ile bakterilerin organik fosfatı çözebilme kabiliyetleri test edilmiştir. Hazırlanan besi yerine ( $8 \mathrm{~g}$ nutrient broth, $28 \mathrm{~g}$ agar, $1 \mathrm{~L}$ damıtık su, \%0.05 phenolphthalein phosphate [otoklav sonrası filtre ile sterilize edilmiş]) ekilen bakteriler $25^{\circ} \mathrm{C}^{\prime}$ de 2 gün inkubasyona bırakılmıştır. Petriler ters çevrilerek kapağına $100 \mu \mathrm{l} \% 25$ amonyak konulmuş ve besi yerindeki kolonilerin renginin pembe-kırmızıya dönmesi pozitif olarak kaydedilmiştir.

Inorganik fosfatı çözebilme: De Freitas ve ark. (1997)'nın önerdiği yöntemden yararlanılmıştır. Besi yerine $(10 \mathrm{~g}$ glukoz, $4 \mathrm{~g} \mathrm{Ca}_{3}\left(\mathrm{PO}_{4}\right)_{2}, 5 \mathrm{~g} \mathrm{NH}_{4} \mathrm{Cl}, 1 \mathrm{~g} \mathrm{NaCl}, 1 \mathrm{~g} \mathrm{MgSO}_{4}, 20 \mathrm{~g}$ agar, $1 \mathrm{~L}$ damıtık su $\mathrm{pH}$ 7.2) bakteriler $10 \mu \mathrm{l} 10^{8}$ hücre $/ \mathrm{ml}$ olacak şekilde damlatılarak ekilmiş ve $25^{\circ} \mathrm{C}^{\prime}$ de 7 gün inkubasyona bırakılmıştır. Koloniler etrafında oluşan açık alan pozitif sonuç olarak kaydedilmiş ve zonun çapı ölçülmüştür.

Indol asetik asit üretimi: Bakterilerin indol 3 asetik asit üretme yetenekleri Patten ve Glick (2002)'in önerdiği yöntemden yararlanılarak saptanmıştır. $25^{\circ} \mathrm{C}^{\prime}$ de $5 \mathrm{ml}$ Triptik Soya Broth (TSB) SIVı besiyerinde gece boyu geliştirilen bakteriler yine $5 \mathrm{ml}$ TSB sıvı besiyerine buradan alınan $20 \mu \mathrm{l}$ ile inokule edilmiştir. Aynı şekilde gece boyu inkubasyonun ardından $20 \mu \mathrm{l}$ olacak şekilde içinde $200 \mu \mathrm{g} / \mathrm{ml}$ L-triptofan bulunan $5 \mathrm{ml}$ Dworkin Foster (DF) tuz minimal besi yerine (4 g K $\mathrm{K}_{2} \mathrm{PO}_{4}, 6 \mathrm{~g} \mathrm{Na}_{2} \mathrm{HPO}_{4}, 0.2 \mathrm{~g} \mathrm{MgSO}_{4} .7 \mathrm{H}_{2} \mathrm{O}, 2 \mathrm{~g}$ glukoz, $2 \mathrm{~g}$ glukonik asit, $2 \mathrm{~g}$ sitrik asit, $2 \mathrm{~g}\left(\mathrm{NH}_{4}\right)_{2} \mathrm{SO}_{4}, 0.1 \mathrm{ml}$ Solüsyon A, $0.1 \mathrm{ml}$ Solüsyon $B, 1 \mathrm{~L}$ damıtık su; [Solüsyon $A$ : $10 \mathrm{mg}$ $\mathrm{H}_{3} \mathrm{BO}_{3}, 11.19 \mathrm{mg} \mathrm{MnSO} \mathrm{M}_{2} \mathrm{H}, 124.6 \mathrm{mg} \mathrm{ZnSO} \mathrm{Z}_{4} .7 \mathrm{H}_{2} \mathrm{O}, 78.22$ mg CuSO $4.5 \mathrm{H}_{2} \mathrm{O}, 10 \mathrm{mg} \mathrm{MoO3,} 100 \mathrm{ml}$ damıtık su; Solüsyon B: $100 \mathrm{mg} \mathrm{FeSO} \mathrm{F}_{4} .7 \mathrm{H}_{2} \mathrm{O}, 10 \mathrm{ml}$ damıtık su]) (Dworkin ve Foster, 1958) alınmıştır. İki günlük çalkalamalı inkubasyonun ardından $1.5 \mathrm{ml}$ bakteri süspansiyonu 5500 g'de $10 \mathrm{dk}$ santrifüj edilmiş, üst sıvıdan $40 \mu \mathrm{l}$ alınmış, mikropleyt kuyularına konulmuş, $160 \mu \mathrm{l}$ Salkowski ayıracı [150 ml $\mathrm{H}_{2} \mathrm{SO}_{4}, 250 \mathrm{ml}$ damıtık su, $7.5 \mathrm{ml} 0.5 \mathrm{M} \mathrm{FeCl}_{3} .6 \mathrm{H}_{2} \mathrm{O}$; (Gordon ve Weber, 1951)] eklenmiş ve karıştırılmıştır. Karanlıkta ve oda sıcaklığında $20 \mathrm{dk}$ bekletmenin ardından $535 \mathrm{~nm}$ 'de spektrofotometrede okunmuş ve hazırlanan IAA standardı (çalışma verileri gösterilmemiştir) ile karşılaştırılarak her bir izolat için IAA miktarları hesaplanmıştır.

Hidrojen siyanid üretimi (HCN): Bakker ve Schippers (1987)'ın önerdiği yöntem ile bakterilerin HCN oluşturup oluşturmadıkları belirlenmiştir. Bunun için \%0.44 glisin içeren $5 \mathrm{ml}$ King B sıvı besi yerine bakteri ekimleri yapılmış, besi yerine değmeyecek şekilde pikrik asit (\%2 sodyum karbonat, \%0.5 pikrik asit) emdirilmiş filtre kağıtları tüp kapaklarına tutturulmuş ve ağızları sıkıca kapatılmıştır. 4
ÖZYILMAZ Ü, BENLIOĞLU K günlük $20^{\circ} \mathrm{C}^{\prime}$ de çalkalamalı inkubasyonun ardından kağıtların portakal renginden kahverengine dönmesi pozitif sonuç olarak değerlendirilmiştir.

Yüzey aktif madde üretimi: Siegmund ve Wagner (1991)'in önerdiği yöntemde belirtilen besi yerine ( $1 \mathrm{~L}$ damıtık su, 20 g glycerol, $0.7 \mathrm{~g} \mathrm{KH}_{2} \mathrm{PO}_{4}, 0.9 \mathrm{~g} \mathrm{Na}_{2} \mathrm{HPO}_{4}, 2 \mathrm{~g} \mathrm{NaNO}, 0.4 \mathrm{~g}$ $\mathrm{MgSO}_{4} .7 \mathrm{H}_{2} \mathrm{O}, 0.1 \mathrm{~g} \mathrm{CaCl} .2 \mathrm{H}_{2} \mathrm{O}, 0.2 \mathrm{~g}$ cethyltrimethyl ammonium bromide, $0.005 \mathrm{~g}$ methylen blue, $15 \mathrm{~g}$ agar ve 2 $\mathrm{ml}$ iz element solüsyonu $\left[\mathrm{FeSO}_{4} \cdot 7 \mathrm{H}_{2} \mathrm{O} 2 \mathrm{~g}\right.$, $\left(\mathrm{NH}_{4}\right)_{6} \mathrm{Mo}_{7} \mathrm{O}_{24} \cdot \mathrm{H}_{2} \mathrm{O} 0.6 \mathrm{~g}, \mathrm{MnSO}_{4} \cdot \mathrm{H}_{2} \mathrm{O} 1.5 \mathrm{~g}$ ve $1 \mathrm{~L}$ damıtık su], toplam besi yerinin pHsı 6.7) bakteri ekimi yapılmıştır. 24 saat $30^{\circ} \mathrm{C}$ 'de gelişen kolonilerin etrafında meydana gelen mavi alan pozitif olarak kaydedilmiş ve çapı ölçülmüştür.

2,4-Diacetylphloroglucinol üretimi: McSpadden Gardener ve ark. (2001)'nın önerdiği yöntemden yararlanılmıştır. Bu yöntem 2,4-DAPG üretiminden sorumlu phID geninin B2BF/BPR4 primer çiftleri kullanılarak (F: ACC CAC CGC AGC ATC GTT TAT GAG C, R: CCG CCG GTA TGG AAG ATG AAA AAG TC) PCR ile amplifiye edilmesi şeklinde gerçekleştirilmiştir. Amplifikasyon toplam $20 \mu \mathrm{l}$ PCR karışımı olacak şekilde $94^{\circ} \mathrm{C}^{\prime} \mathrm{de} 3 \mathrm{dk}$ başlangıç denatürasyonu, $30 \times$ $\left(94^{\circ} \mathrm{C}^{\prime}\right.$ de $10 \mathrm{sn}$ denatürasyon, $60^{\circ} \mathrm{C}^{\prime}$ de $15 \mathrm{sn}$ annealing ve $72^{\circ} \mathrm{C}^{\prime}$ de 15 sn uzama) ve $72^{\circ} \mathrm{C}^{\prime}$ de $5 \mathrm{dk}$ son uzama koşullarında gerçekleştirilmiştir (Eppendorf Mastercycler). Amplifikasyonun gerçekleşip gerçekleşmediğinin belirlenmesi için ürünler \%1.5'lik agaroz jelde yürütülmüş, etidyum bromür ile boyanmış ve jel görüntüleme sistemi ile fotoğrafı çekilmiştir. 629 baz çifti (bç) büyüklüğündeki bantların varlığı pozitif olarak değerlendirilmiştir.

Siderofor Üretimi: $\mathrm{Bu}$ testler için Blue CAS besiyeri kullanılmıştır (Schwyn ve Neilands, 1987). Testlerde kullanılan kasamino asit solüsyonu Cox (1994)'e göre demirden arındırılmıştır. Beş günlük $25^{\circ} \mathrm{C}^{\prime}$ de inkubasyonun ardından koloniler etrafında oluşan portakal rengi alan pozitif olarak değerlendirilmiş, çapı ölçülerek kaydedilmiştir. Ayrıca, metabolit üretimi test edilen bu bakterilerin yağ asitleri metil ester (FAME) profilleri çıkarılmış ve tanılanmaya çalışılmıştır (Agilent 6890N, Sherlock MIS, TSBA40 kütüphanesi) (Midi, 2006).

\section{$P$. cactorum İzolatlarının Virülensliğinin Belirlenmesi}

$P$. cactorum izolatlarının virülensliğinin belirlenmesine yönelik test çalışmalarında kullanmak üzere ilk önce çilek fideleri saksılara dikilerek 3 hafta boyunca taze kök oluşturması sağlanmıştır. Daha sonra bitkiler dikkatlice alınarak ağırlıkları ölçülmüş ve steril yetiştirme harcı ile hazırlanmış \%1 (hacim/hacim) inokulumunlu toprağa şaşırtılmıştır (Kurze ve ark., 2001; Martin, 2000). İnokulum, patojenlerin $250 \mathrm{ml}$ buğday kepeği, $250 \mathrm{ml}$ vermiculit, $30 \mathrm{gr}$ soya unu ve $84 \mathrm{ml}$ saf sudan oluşan kepek besi yerine ekilmesi ve $22^{\circ} \mathrm{C}^{\prime}$ de 4 hafta inkube edilmesi şeklinde hazırlanmıştır. Bitkilerin beş hafta yetiştirilmesi sonunda, Kurze ve ark. (2001)'nın önerdiği yöntemde değişiklik 
yapılarak hazırlanan 0-3 skalası (0: belirti yok, 1: yaprak uçlarında kuruma ve yaprak sapında kararma ama henüz solgunluk yok, 2: solgun bitki, 3: ölü bitki) kullanılarak değerlendirmeler yapılmıştır. Daha sonra bitkiler saksılardan dikkatlice sökülmüş, topraklarından arındırılmış, tekrar tartılmıştır ve başlangıçtaki ağırlığı ile karşılaştırılarak oransal değişim hesaplanmıştır. Denemeler tesadüf parselleri deneme desenine göre üç tekerrürlü olarak yapılmıştır.

\section{Saksı Koşullarında Biyolojik Kontrol Testleri}

$\mathrm{Bu}$ testlerde; $P$. cactorum izolatlarının virülenslik testi sonucunda en yüksek hastalık skala değeri alan izolatlardan biri olan P5 izolatı kullanılmıştır. Antagonist bakterilerin etkinliğinin değerlendirildiği saksı denemelerinde, bitki hazırlığı ve inokulumlu toprak hazırlığı yukarıda anlatıldığı gibi yapılmıştır. Bitkiler köklendirilip patojen inokule edilmiş toprağa alınırken bitkilerin kökleri $10^{9}$ hücre $/ \mathrm{ml}$ yoğunluğundaki antagonsit bakteri süspansiyonuna yarım saat süre ile daldırılmıştır. Tesadüf parselleri deneme desenine göre üç tekerrürden oluşan çalışmada değerlendirme şaşırtmadan 5 hafta sonra yukarıda anlatılan skala kullanılarak yapılmış, Towsend-Heuberger formülü ile hastalık oranlarına çevrilmiş ve Abbott formülü ile etki oranları hesaplanmıştır (Karman, 1971).

\section{BULGULAR ve TARTIŞMA}

Bitkilerin kök bölgeleri salgıladıkları maddeler nedeniyle içinde biyolojik savaş ajanlarının da bulunduğu bir mikroorganizma yoğunluğuna sahiptir (Sorensen, 1997). Farklı bitki tür ve çeşitlerinin kök bölgesindeki mikroorganizmaların farklı olduğu da bilinmektedir (Smalla ve ark., 2001). Bu çalışmada değişik bitkilerin kök bölgelerinden toplam 362 adet antagonist adayı elde edilmiştir. Yapılan ikili kültür ön eleme testlerinde 101 izolatın potansiyel antagonist olabileceği belirlenmiştir. İkili kültürde ön inceleme şeklinde değerlendirilen bu 101 bakteri detaylı olarak ikili kültür çalışmalarına alınmış ve etmeni engelleme oranları hesaplanmıştır. Etmene; 35 çilek, 6 bakla, 10 brokoli, 12 karnabahar, 2 kırmızı lahana, 5 lahana, 6 turp, 3 yabani turp, 3 darıcan ve 6 çoban çantası izolatının az ya da çok bir engelleme gösterdiği saptanmıştır. Detaylı ikili kültür testlerine göre; toplam 88 adet $P$. cactorum'a etkili antagonist elde edilmiş, bunlardan 37 tanesi $\% 40$ ve üzeri bir engelleme göstermiş ve maksimum engelleme \%84 (6ba3) olarak belirlenmiştir. Bu antagonistlerden 5 tanesi tütün yapraklarında aşırı duyarlılık belirtisi göstermiş ve diğer bitkilerde de buna benzer hassasiyetin meydana gelebileceği düşüncesiyle elenmiştir. Antagonistlerin hepsi $25^{\circ} \mathrm{C}^{\prime}$ de iyi bir gelişim gösterirken 33 tanesi $37^{\circ} \mathrm{C}^{\prime}$ de ya hiç gelişmemiş ya da sınırlı bir gelişim sergilemiştir, bu nedenle çalışmada değerlendirilmemiştir. Ayrıca 5 izolat gram pozitif 66 bulundukları için çalışma konusu dışında tutulmuştur. Çalışma dışında tutulan izolatlar ve ikili kültür testlerinde öne çıkan izolatlar değerlendirildiğinde nihai antagonist sayısı 24'e düşürülmüştür $(3 \mathrm{k} 9,3 \mathrm{mb} 12,3 \mathrm{msss} 12,3 \mathrm{msss} 5$, 3ss9, 3tg13, 3tg8, 4b7, 4k1, 6b2, 6b6, 6ba2, 6ba3, 6ba6, 6k4, 6k8, 6l10, 6l14, 6t14, 7ec11, ka, ke, mbe ve mbj).

\section{Sekonder Metabolit Üretme Kabiliyetleri}

Antagonist bakterilerin metabolit üretim yetenekleri; kitinaz, proteaz, pektinaz, selülaz, DNAz, fosfataz enzim aktiviteleri ile inorganik fosfatı çözebilme kabiliyetlerinin araştırılması ile gerçekleştirilmiştir. Aynı zamanda indol asetik asit (IAA), hidrojen siyanid (HCN), yüzey aktif madde, 2,4-Diacetylphloroglucinol (2,4-DAPG) ve siderefor üretme yetenekleri de araştırılmıştır.

Çizelge 1 incelendiğinde; kitinaz ve selülaz enzim aktivitesini sadece çalışmalarda kontrol olarak kullanılan HRO-C48 (Serratia plymuthica) göstermiştir. Değişen miktarlardaki proteaz aktivitesi 3k9, 3msss12, 3ss9, 4b7, 6ba2, 6ba3, 6ba6, 6I10, 6I14, 7ec11, ke, mbe, mbj ve HRO-C48 izolatlarında gözlenirken pektinaz aktivitesine sahip bir izolat bulunmamıştır. 6I10, 6I14 ve 6t14 izolatlarında DNAz aktivitesi saptanmış ancak HRO-C48 izolatına göre daha düşük olduğu görülmüştür. $3 \mathrm{k} 9,3 \mathrm{mb} 12,3 \mathrm{msss} 5,3 \mathrm{ss} 9$, 3tg13, 3tg8, 4b7, 4k1, 6b2, 6b6, 6ba3, ba6, 6k8, 6l10, 6l14, $6 t 14, k a, k e$, mbe, mbj ve E11 izolatları değişik oranlarda inorganik fosfatı çözebilirken 4b7, 6b2, $6 b 6$ ve HRO-C48 izolatları fosfataz pozitif olarak bulunmuştur.

Antagonist bakterilerin IAA üretim miktarlarının test edildiği denemede spektrofotometrede okunan absorbans değerleri standart seri denkleminde $\left\langle r^{2}=0.97\right.$, veri sunulmamıştır) yerine konulduğunda $6 \mathrm{k} 4$ izolatının 62.4 ve $6 \mathrm{k} 8$ izolatının ise $1.9 \mu \mathrm{g} / \mathrm{ml}$ oranında IAA ürettiği hesaplanmıştır. 3k9, 4b7, 6I10, 6I14, mbj, 3mb12, 3msss12, 3msss5, 3ss9, 3tg8, 4k1, 6b6, 6ba2, 6ba3, 6ba6, 6t14, 7ec11, ke, mbe ve E11 izolatlarının değişen oranlarda HCN ürettiği bulunurken; 6l10, 6ba2, 3ss9, 3k9, 3tg8, 6ba3, 6ba6, 6l14, 6t14, ke, mbj ve E11 izolatlarının yine değişen oranlarda yüzey aktif madde ürettiği saptanmıştır.

2,4-DAPG üretimini saptamak amacıyla yapılan PCR çalışmasında amplifikasyon sonunda phID genine özgü primer çiftlerinin 629 bç büyüklüğünde bant oluşturduğu gözlenmiş ve $3 \mathrm{~kg}$, 3mb12, 3msss5, 3ss9, 3tg13, 3tg8, 4b7, 6ba2, 6ba3, 6ba6, 6l10, 6l14, 6t14, ka, ke mbj ile E11 izolatları pozitif olarak bulunmuştur (Şekil 1).

Son olarak izolatların büyük bir kısmının farklı oranlarda siderefor ürettiği belirlenmiştir (6ba3, 6ba6, 6ba2, 3k9, 3mb12, 3msss5, 3ss9, 3tg13, 3tg8, 4b7, 4k1, 6l10, 6I14, $6 t 14,7 e c 11, k a, k e, m b j$ ve E11). Yapılan yağ asitleri profili analizine göre izolatların tümünün Pseudomonas genusunda yer aldığı belirlenmiştir. 


\begin{tabular}{|c|c|c|c|c|c|c|c|c|c|c|c|c|c|c|c|}
\hline izolat & 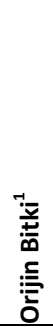 & 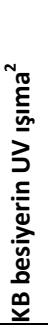 & 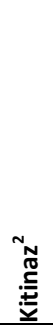 & 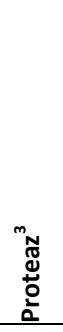 & 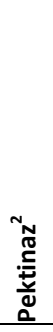 & ${ }_{N}^{N}$ & $\sum_{0}^{+N}$ & $\begin{array}{l}n^{n} \\
\mathbb{N} \\
\frac{\pi}{\pi} \\
0 \\
\end{array}$ & 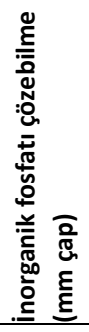 & 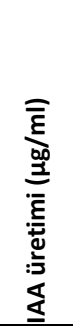 & 는 & 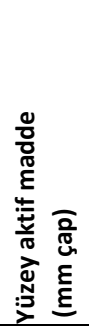 & 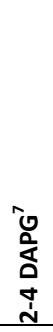 & 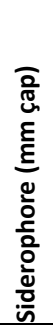 & 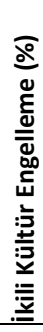 \\
\hline $3 k 9$ & Ç & + & - & + & - & - & - & - & 9 & 0 & ++++ & 20 & + & 12 & 13 \\
\hline $3 m b 12$ & Ç & + & - & - & - & - & - & - & 9 & 0 & ++ & 0 & + & 16 & 22 \\
\hline $3 m s s s 12$ & Ç & + & - & +++ & - & - & - & - & 0 & 0 & + & 0 & - & 0 & 60 \\
\hline $3 m s s s 5$ & Ç & + & - & - & - & - & - & - & 11 & 0 & +++ & 0 & + & 15 & 62 \\
\hline $3 s s 9$ & Ç & + & - & + & - & - & - & - & 9 & 0 & +++ & 21 & + & 15 & 22 \\
\hline $3 \operatorname{tg} 13$ & Ç & + & - & - & - & - & - & - & 13 & 0 & - & 0 & + & 12 & 66 \\
\hline $3 \operatorname{tg} 8$ & Ç & - & - & - & - & - & - & - & 12 & 0 & + & 14 & + & 16 & 75 \\
\hline $4 b 7$ & B & + & - & +++ & - & - & - & ++ & 9 & 0 & ++++ & 0 & + & 5 & 78 \\
\hline $4 \mathrm{k} 1$ & $\mathrm{~K}$ & + & - & - & - & - & - & - & 13 & 0 & + & 0 & - & 6 & 56 \\
\hline $6 b 2$ & B & + & - & - & - & - & - & + & 13 & 0 & - & 0 & - & 0 & 45 \\
\hline $6 b 6$ & B & + & - & - & - & - & - & + & 12 & 0 & ++ & 0 & - & 0 & 50 \\
\hline $6 b a 2$ & $\mathrm{Ba}$ & + & - & ++ & - & - & - & - & 0 & 0 & +++ & 22 & + & 22 & 72 \\
\hline $6 b a 3$ & $\mathrm{Ba}$ & + & - & + & - & - & - & - & 10 & 0 & ++ & 14 & + & 25 & 84 \\
\hline 6 ba6 & $\mathrm{Ba}$ & + & - & ++ & - & - & - & - & 8 & 0 & ++ & 16 & + & 23 & 83 \\
\hline $6 \mathrm{k} 4$ & K & + & - & - & - & - & - & - & 0 & 62.4 & - & 0 & - & 0 & 25 \\
\hline $6 \mathrm{k} 8$ & $\mathrm{~K}$ & + & - & - & - & - & - & - & 10 & 1.9 & - & 0 & - & 0 & 28 \\
\hline 6110 & L & + & - & ++ & - & - & \pm & - & 11 & 0 & ++++ & 23 & + & 15 & 27 \\
\hline 6114 & $\mathrm{~L}$ & + & - & ++ & - & - & \pm & - & 8 & 0 & ++++ & 19 & + & 18 & 23 \\
\hline $6 \mathrm{t} 14$ & $\mathrm{~T}$ & - & - & - & - & - & \pm & - & 9 & 0 & + & 14 & + & 23 & 67 \\
\hline 7ec11 & Ç & + & - & +++ & - & - & - & - & 0 & 0 & ++ & 0 & - & 5 & 60 \\
\hline ka & Ç & + & - & - & - & - & - & - & 11 & 0 & - & 0 & + & 15 & 63 \\
\hline ke & Ç & + & - & + & - & - & - & - & 12 & 0 & +++ & 11 & + & 14 & 71 \\
\hline mbe & Ç & + & - & + & - & - & - & - & 14 & 0 & ++ & 0 & - & 0 & 42 \\
\hline $\mathrm{mbj}$ & Ç & + & - & + & - & - & - & - & 11 & 0 & ++++ & 14 & + & 17 & 56 \\
\hline *HRO-C48 & Ko & $\mathrm{nt}$ & + & + & - & + & + & +++ & 0 & 0 & - & 0 & nt & 0 & 49 \\
\hline *E11 & Ko & nt & - & - & - & - & - & - & 13 & 0 & + & 17 & + & 16 & 63 \\
\hline *ECC-133 & & nt & nt & nt & + & nt & nt & nt & nt & nt & nt & nt & nt & nt & nt \\
\hline
\end{tabular}

${ }^{1}$ Ç: çilek, B: brokoli, K: karnabahar, Ba: bakla, L: lahana, T: turp, Ko: kolza

2 +: pozitif sonuç, -: negatif sonuç

${ }^{3}$ Açık zonun çapı $5 \mathrm{~mm}$ 'ye kadar olanlar +, 5-10 mm olanlar ++, $10 \mathrm{~mm}$ 'den büyük olanlar +++

${ }^{4}+$ : pozitif sonuç, \pm : zayıf pozitif, -: negatif sonuç

${ }^{5}$ Oluşan kırmızı rengin şiddetine göre; kırmızı ise +++ , açık kırmızı ise ++ , hafif pembemsi ise +

${ }^{6}$ Elde edilen kahverenginin tonuna göre en koyu renk ++++ ve en açık + olmak üzere pozitif sonuç dört sınıfa ayrılmıştır.

${ }^{7}$ Yürütülen jelde 629 bp büyüklüğünde bant oluşumu +

* Pozitif ve negatif kontroller (HRO-C48: Serratia plymuthica, E11: Pseudomonas fluorescens, ECC-133: Erwinia corotovora subsp. carotovora)

nt: Test edilmedi 

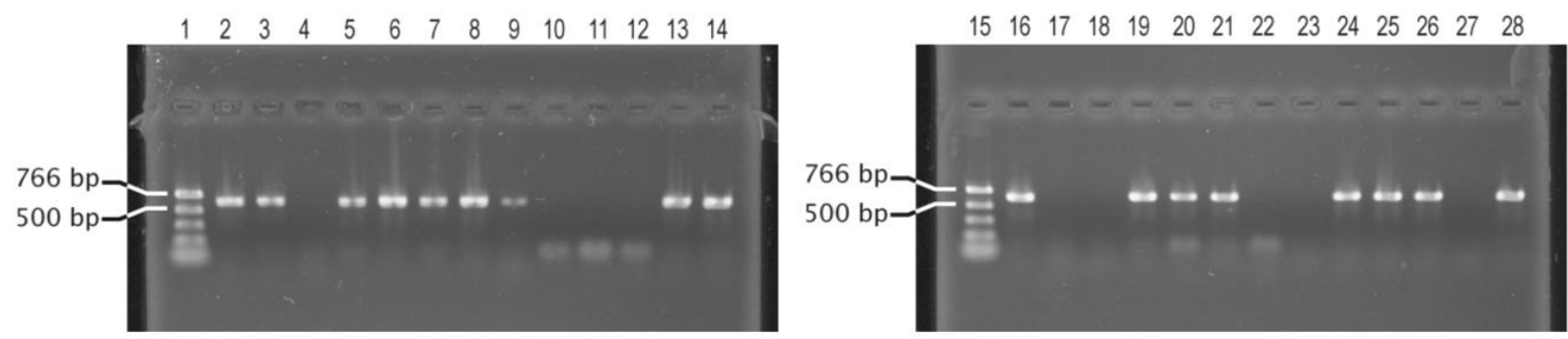

Şekil 1. B2BF/BPR4 primer çiftleriyle yapılan PCR sonucunda elde edilen ürünlerin \%1.5 agaroz jelde elektroforez edilip ethidium bromide ile boyanması ile gözlenen 629 bç büyüklüğündeki bantlar. 1 ve 15: Marker (New England Biolabs), 2: 3k9, 3: 3mb12, 4: 3msss12, 5: 3msss5, 6: 3ss9, 7: 3tg13, 8: 3tg8, 9: 4b7, 10: 4k1, 11: 6b2, 12: 6b6, 13: 6ba2, 14: 6ba3, 16: 6ba6, 17: 6k4, 18: 6k8, 19: 6l10, 20: 6l14, 21: 6t14, 22: 7ec11, 23: steril saf su, 24: E11, 25: ka, 26: ke, 27: mbe, 28: mbj

\section{$P$. cactorum İzolatlarının Virülensliğinin Belirlenmesi}

Yapılan hastalık etmeni virülenslik belirleme testleri sonucunda P3, P14, P13, P5 ve P12 P. cactorum izolatlarının diğerlerine göre daha virülent olduğu, yaş ağırlık değişimi açısından bakıldığında ise $\mathrm{P} 3, \mathrm{P} 7, \mathrm{P} 14, \mathrm{P} 4, \mathrm{P} 2 / 01$, P5 ve P13 izolatlarının öne çıktığı görülmektedir (Çizelge 2). Tüm tekerrürlerde her bir skala değerine denk gelen ağırlık değişimlerinin patojen bağımsız olarak ortalaması alındığında, skala değeri ile ağırlık değişim oranı arasında negatif yönde bir korelasyonun olduğu hesaplanmıştır $\left(R^{2}=\right.$ 0.7573 ). Çizelge 2 'de verilen grafiğe bakıldığında 2 skala değerine ulaşan bir bitkinin ileriki durumlarda artık daha da ağırlık kaybetmediği görülmektedir.

\section{Saksı Koşullarında Biyolojik Kontrol Testleri}

Skala değeri ve ağırlıktaki değişim oranı arasında hesaplanan bu ilişkiden dolayı saksı koşullarında biyolojik kontrol testlerinde değerlendirmeler skala değerleri dikkate alınarak yapılmıştır. Bu etki denemelerinde $3 s s 9$ ve 6110 antagonist bakterilerinin çilek bitkisini $\% 50$ oranında koruduğu saptanırken diğer bakterilerin bir koruma sağlayamadığı hatta bazılarının hastalığı teşvik ettiği de görülmüştür (Çizelge 3). Vestberg ve ark. (2004)'nın yapmış olduğu çalışmada $P$. cactorum'un çilekte kontrolü için kullandığı bazı antagistlerin hastalık artışına neden olduğuna değinmiştir. Aynı şekilde Berg ve ark. (2001) çileklerde Verticillium solgunluğuna karşı yaptığı denemede bazı mikroorganizmaların hastalık artışına neden olduğunu bildirmiştir.

\section{SONUÇ}

Çilek bitkilerinde kök ve taç çürüklüğüne neden olan Phytophthora cactorum'a karşı, çilek ve bazı bitkilerin köklerinden izole edilen antagonist bakteriler ile biyolojik mücadeleyi hedefleyen bu çalışmada farklı koloni

Çizelge 2. Çilek bitkilerinde Phytophthora cactorum izolatlarına yapılan virülenslik testi sonucunda beşinci haftada elde edilen skala değerleri ortalamaları ve bitkilerde meydana gelen ağırlık değişim oranları (\%) (sol). Skala değeri ile ağılık değişimi arasındaki ilişki (sağ)

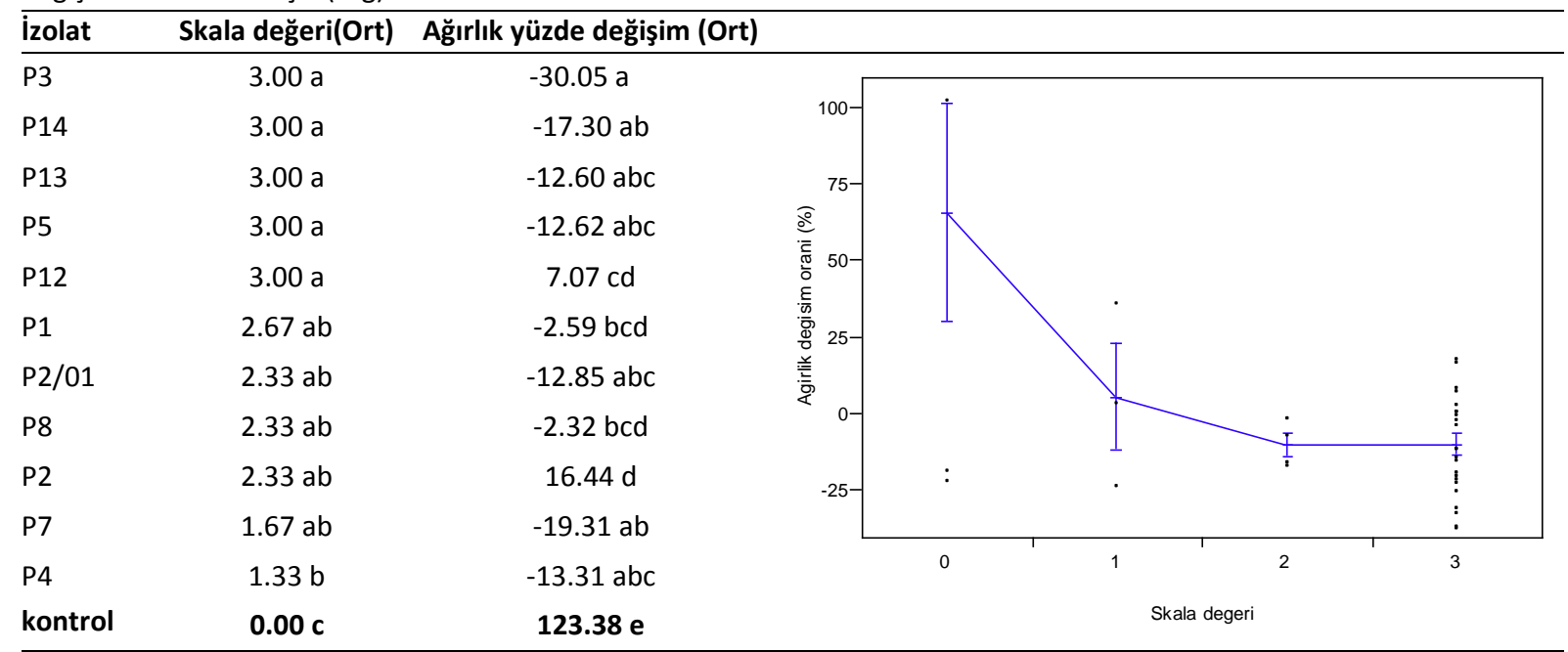

Üç tekerrürün ortalamasıdır, aynı sütünda aynı harfle gösterilen değerler arasında istatistiki açıdan fark yoktur (LSD, $\mathrm{P}<0.05)$, skala değerlerine sqrt(sakala değeri +0.5 ) transformasyonu yapılmıştır 
Çizelge 3. Antagonist bakterilerin çilek bitkisin Phytophthora cactorum'a karşı koruma durumları

\begin{tabular}{|c|c|c|c|}
\hline \multirow{2}{*}{$\begin{array}{l}\text { İzolat } \\
\text { kontrol (hastalıksız) }\end{array}$} & \multicolumn{3}{|c|}{ Skala Ort $^{1}$ Yüzde Hast. ${ }^{2}$ Yüzde Etki ${ }^{2}$} \\
\hline & $0.00 \mathrm{a}$ & 0 & \\
\hline $3 s s 9$ & $0.67 \mathrm{ab}$ & 22 & 50 \\
\hline 6110 & $0.67 \mathrm{ab}$ & 22 & 50 \\
\hline HRO-C48 & $1.00 \mathrm{bc}$ & 33 & 25 \\
\hline ka & $1.00 \mathrm{bcd}$ & 33 & 25 \\
\hline $6 \mathrm{~b} 2$ & $1.33 \mathrm{bcde}$ & 44 & 0 \\
\hline $6 \mathrm{ba} 6$ & 1.33 bcde & 44 & 0 \\
\hline $6 k 4$ & 1.33 bcde & 44 & 0 \\
\hline $3 m s s s 5$ & 1.33 bcde & 44 & 0 \\
\hline kontrol (hastalıklı) & 1.33 bcde & 44 & 0 \\
\hline E11 & 1.67 cdef & 56 & 0 \\
\hline $3 m s s s 12$ & $1.67 \mathrm{cdef}$ & 56 & 0 \\
\hline $6 b 6$ & $1.67 \mathrm{cdef}$ & 56 & 0 \\
\hline 6114 & $1.67 \mathrm{cdef}$ & 56 & 0 \\
\hline $3 \operatorname{tg} 8$ & $1.67 \mathrm{cdef}$ & 56 & 0 \\
\hline $6 \mathrm{k} 8$ & $1.67 \mathrm{cdef}$ & 56 & 0 \\
\hline $6 \mathrm{t} 14$ & $1.67 \mathrm{cdef}$ & 56 & 0 \\
\hline ke & 2.00 def & 67 & 0 \\
\hline $4 \mathrm{k} 1$ & $2.00 \mathrm{def}$ & 67 & 0 \\
\hline mbe & $2.00 \mathrm{def}$ & 67 & 0 \\
\hline $6 \mathrm{ba} 2$ & $2.00 \mathrm{def}$ & 67 & 0 \\
\hline $3 \operatorname{tg} 13$ & $2.00 \mathrm{def}$ & 67 & 0 \\
\hline $3 \mathrm{mb} 12$ & $2.00 \mathrm{def}$ & 67 & 0 \\
\hline $7 e c 11$ & 2.33 ef & 78 & 0 \\
\hline $3 \mathrm{k} 9$ & $2.33 \mathrm{ef}$ & 78 & 0 \\
\hline 6 ba3 & 2.33 ef & 78 & 0 \\
\hline $\mathrm{mbj}$ & $2.67 \mathrm{f}$ & 89 & 0 \\
\hline $4 \mathrm{~b} 7$ & $2.67 f$ & 89 & 0 \\
\hline
\end{tabular}

${ }^{1}$ Aynı harfle gösterilen değerler arasında istatistiki açıdan fark yoktur (LSD, $\mathrm{P}<0.05$ )

${ }^{2}$ Yüzde hastalık değerleri Towsend-Heuberger, yüzde etki Abbott formüllerine göre hesaplanmıştır

morfolojisine sahip toplam 362 bakteri izole edilmiştir. Yapılan ikili kültür testleri sonucunda bu sayı ilk önce 101'e ve daha sonra yapılan ek test ve değerlendirmeler ile de 24 'e düşürülmüştür. Ön eleme testleri sonucunda seçilen bu 24 bakteri geri kalan testlerin ve saksı denemelerinin hepsinde değerlendirilmiştir.

Biyokontrol çalışmalarına başlamadan önce mevcut $P$. cactorum izolatlarının virülenslik belirleme testleri yapılmıştır. Bu testler sonucunda hastalık skalası ile hastalıktan dolayı yaş ağılıkta meydana gelen azalma arasında bir bağıntının olduğu ve skala değerlendirmesinin hastalığın ölçülmesinde kullanılabilir olacağı kanısına varılmıştır.

Bakterilerin hastalığa karşı antagonistik etkileri saksı koşullarında değerlendirildiği denemede en yüksek hastalık skala değerine sahip olan izolarlardan biri olan P5 kullanılmıştır. Denemede 3ss9 ve 6110 izolatlarının etkili olduğu bulunmuş ve ümitvar sonuçlar verdiği görülmüştür.
ÖZYILMAZ Ü, BENLIOĞLU $K$ Ancak bu izolatların ikili kültür test sonuçlarının diğer antagonistlere göre daha az olduğu görülmektedir. Bununla birlikte bazı antagonistlerin $(\mathrm{mbj}, 4 \mathrm{~b} 7)$ saksı denemelerinde hastalığın şiddetini istatistiki olarak arttırdığı görülmüştür. Bu izolatlar ikili kültür testlerinde iyi birer engelleyici olarak karşımıza çıkmıştır. Biyolojik mücadele araştırmalarında laboratuvar ve doğa çalışmaları arasındaki uyuşmazlık karşılaşılan bir durumdur (Fravel, 1988). Antagonist bakterilerin seçiminde in-vitro testlerin in-vivo çalışmalar ile desteklenerek sonuca gidilmesi gerektiği görülmüştür. Antagonist arayışı içinde, iklim odası çalışmalarının mevcut antagonist adaylarının hepsine ya da büyük çoğunluğuna uygulanabilmesi ancak koparılmış bitki parçaları veya doku kültürü ile üretilmiş bitkiciklerin devreye sokulması ile mümkün görülmektedir.

Belirli bir hastalığa etkili antagonist bakterinin aynı zamanda farklı patojenlere de etki edebileceği bilinmektedir (Berg ve ark., 2000a; Berg ve ark., 2001; Krechel ve ark., 2002). Çilek üretiminde toprak dezenfeksiyonu yapılmakta ve bu birçok toprak kaynaklı patojeni kontrol edebilmektedir. Ancak günümüzde Aydın ilinde kömür çürüklüğüne neden olan Macrophomina phaseolina majör patojen durumuna geçmeye başlamıştır. Çilekte biyolojik mücadele çalışmalarında bu hastalığın da göz önünde bulundurulması ve mevcut izolatların bu etmene karşı da değerlendirilmesi çalışılabilecek konular arasındadır.

\section{Teşekkür}

Phytophthora cactorum izolatlarını sağladıkları için Prof. Dr. Seher Benlioğlu ve Prof. Dr. Ayhan Yıldız'a, çalışmada kontrol izolatı olarak kullanılan Serratia plymuthica (HROC48) ve Pseudomonas fluorescens (E11) izolatlarını sağladığı için Prof. Dr. Gabriele Berg'e, yağ asitleri profillerinin çıkarılmasına imkan sağladığı için Prof. Dr. Fikrettin Şahin'e ve 1030146 nolu proje ile maddi destek sağlayan TÜBiTAK'a teşekkür ederiz.

\section{KAYNAKLAR}

Andro T, Chambost JP, Kotoujansky A, Cattano J, Bertheau Y, Barras F, Van Gijsegem F, Coleno A (1984) Mutants of Erwinia chrysantemi Defective in Secretion of Pectinase and Cellulase. J. Bacterial. 160:119-1203.

Bakker AW, Schippers B (1987) Microbial Cyanide Production in the Rhizosphere in Relation to Potato Yield Reduction and Pseudomonas spp-mediated Plant Growth-stimulation. Soil Biol. Biochem. 19(4): 451-457.

Benlioğlu S, Yıldız A, Döken T (2004) Studies to Determine the Causal Agents of Soilborne Fungal Diseases of Strawberries in Aydin and to Control them by Soil Disinfestation. J. Phytopathology 152(18): 509-513

Benlioğlu S, Boz Ö, Yıldız A, Kaşkavalıı G, Benlioğlu K (2005) Alternative Soil Solarization Treatments For the Control of Soil-borne Diseases and Weed of Strawberry in the Western Anatolia of Turkey. J. Phytopathology 153: 423-430. 
Benlioğlu S, Dinler H, Yildiz A, Özyilmaz Ü, Benlioğlu K (2018) Türkiye'de Çilek Fidelerinde Karşılaşılan Sorunlar. Adnan Menderes Üniversitesi Ziraat Fakültesi Dergisi 15(1): 121-126.

Beraha L (1968) A Rapid Method for the Preparation of A Semi-Solid Agar Medium for Detection of Pectolytic Enzyme Activity in Erwinia Carotovora. Plant Disease Reporter 52(2) February 1968.

Berg G (1996) Rhizobacteria of Oilseed Rape Antagonistic to Verticillium dahliae ver. Iongisporum STRAK. Zeitschrift für Planzenkrankheiten und Pflanzenschutz 103(1): 20-30.

Berg G, Kurze S, Buchner A, Wellington EM, Smalla K (2000a) Successful Strategy for the Selection of New Strawberry-associated Rhizobacteria Antagonistic to Verticillium Wilt. Canadian-Journal-of-Microbiology. 46(12): 1128-1137.

Berg G, Frankowski J, Bahl H (2000b) Interactions Between Serratia plymuthica and the Soil Borne Pathogen Verticillium longisporum. In: Tjamos EC, Rowe C, Heale JB, Fravel DR (eds.), Advances in Verticillium Research and Disease Management. St Paul, MN, USA: American Phytopathological Society Press, 269273.

Berg G, Fritze A, Roskot N, Smalla K (2001) Evaluation of Potential Biocontrol Rhizobacteria from Different Host Plants of Verticillium dahliae Kleb. Journal of Applied Microbiology 91(6):963-971.

Bora T, Özaktan H (1998) Bitki Hastalıklarıyla Biyolojik Savaş. Prizma Matbaası, İzmir, 205 s.

Browne G, Becherer $\mathrm{H}$, Mclaughlin S, Fennimore S, Duniway J, Martin F, Ajwa H, Winterbottom C, Guerrero L (2003) Integrated Management of Phytophthora on Strawberry without Methyl Bromide. Proceedings of Methyl Bromide Alternatives Conference.

Cox CD (1994) Deferration of Laboratory Media and Assays for Ferric and Ferrous lons. Methods Enzymol. 235: 315-372.

De La Fuente L, Bajsa N, Bagnasco P, Quagliotto L, Thomashow L, Arias A (2000) Antibiotic Production by Biocontrol Pseudomonas fluorescens Isolated from Forage Legume Rhizosphere. Proceedings of the 5th International PGPR Workshop, Córdoba, Argentina.

De los Santos B, Barrau C, Romero F (2003) Strawberry Fungal Disease. Food, Agriculture \& Environment Vol. 1 (3\&4): 129-132.

De Freitas JR, Banerjee MR, Germida JJ (1997) Phosphatesolubilizing Rhizobacteria Enhance the Growth and Yield But Not Phosphorus Uptake of Canola (Brassica napus L.). Biol Fertil Soils 24:358-364.

Dworkin M., Foster J (1958) Experiment with Some Microorganisms which Utilize Ethane and Hydrogen. J. Bacteriol 75: 592-601.

Eikemo H, Stensvand A, Tronsmo AM (2000) Evaluation of Methods of Screening Starwberry Cultivars for Resistance to Crown Rot Caused by Phytophthora cactorum. Ann. appl. Biol. 137: 237-244.
Eikemo H, Stensvand A, Tronsmo AM (2003) Induced Resistance as a Possible Means to Control Diseases of Strawberry Caused by Phytophthora spp. Plant Dis. 87: 345-350.

Fravel DR (1988) Role of Antibiosis in the Biocontrol of Plant Diseases. Annu. Rev. Phytopathol. 26: 75-91.

Gamliel A, Katan J (1993) Suppression of Major and Minor Pathogens by Fluorescent Pseudomonads in Solarized and Nonsolarized Soils. Phytopathology 83: 68-75.

Golzar H, Phillips D, Mack S (2007) Occurrence of Strawberry Root and Crown Rot in Western Australia. Australian Plant Disease Notes 2:145-147.

Gordon SA, Weber RP (1951) Colorimetric Estimation of Indoleacetic Acid. Plant Physiology 26: 192-195.

Gulati MK, Koch E, Zeller W, Sisler HD (1999) Isolation and Identification of Antifungal Metabolites Produced by Fluorescent Pseudomonas, Antagonist of Red Core Disease of Strawberry. Modern Fungicides and Antifungal Compounds II. 12th International Reinhardsbrunn Symposium, Friedrichroda, Thuringia, Germany, pp 437-444.

Holt JG, Krieg NR, Sneath PHA, Staley JT, Williams ST (1994). Bergey's Manual of Determinative Bacteriology. Ninth edition. Williams \& Wilkins, Baltimore, MD.

Irzykowska L, Irzykowski W, Jarosz A, Golebniak B (2005) Association of Phytophthora citricola with Leather Rot Disease of Strawberry. J. Phytopathology 153: 680685.

Jeffries CD, Holtmann DF, Guse DG (1957) Rapid Method for Determining the Activity of Microorganisms on Nucleic Acid. J. Bact., 73: 590-591.

Karman M (1971) Bitki Koruma Araştırmalarında Genel Bilgiler, Denemelerin Kuruluşu ve Değerlendirlme Esasları. T.C. Tarım Bakanlığı Zirai Mücadele ve Zirai Karantina Genel Müdürlüğü Yayınları, 279s.

King EO, Ward MK, Raney DE (1954) Two Simple Media for the Demostration of Pyocyanin and Fluorescein. J. Lab. Clin. Med. 44: 301-307.

Klement Z (1963) Rapid Detection of the Pathogenisty of Phytopathogenic Pseudomonas. Nature, 199: 299300p.

Klement Z, Rudolph K, Sands DC (1990) Methods in Phytobacteriology. Akademiai Kiado, Budapest, 568p.

Koch E, Kempf HJ, Hessenmüller A (1998) Characterization of the Biocontrol Activity and Evaluation of Potential Plant Growth-promoting Properties of Selected Rhizobacteria. Journal of Plant Disease and Protection, 105(6): 567-580.

Krechel A, Faupel A, Hallmann J, Ulrich A, Berg G (2002) Potato-associated Bacteria and their Antagonistic Potantial towards Plant-pathogenic Fungiand the Plant-parasitic Nematode Meloidogyne incognita (Kofoid \& White) Chitwood. Can. J. Microbiol. 48: 772786.

Kurze S, Bahl H, Dahl R, Berg G (2001) Biological Control of Fungal Strawberry Disease by Serratia plymuthica HRA-C48. Plant Dis. 85: 529-534. 
Maas JL (1998) Compendium of Strawberry Diseases, Second edition. APS press Minnesota USA, 98p.

Martin FN (2000) Rhizoctonia spp. Recovered from Strawberry Roots in Central Coastal California. Phytopathology 90: 345-353.

Martin FN, Bull CT (2002) Biological Approaches for Control of Root Pathogens on Strawberry. Phytopathology 92: 1356-1362.

McSpadden Gardener BB, Mavrodi DV, Thomashow LS, Weller DM (2001) A Rapid Polymerase Chain Reaction-based Assay Characterizing Rhizosphere Population of 2,4-Diacetylphloroglucinol-producing Bacteria. Phytopathology 91: 44-54.

Midi (2006) Identification of Bacteria by Gas Chromatography of Cellular Fatty Acids. Microbial Identification System, Technical operating manual. MIDI, Inc., 115 Barksdale Prof. Center, Newark, Delaware.

Patten CL, Glick BR (2002) Role of Pseudomonas putida Indole acetic Acid in Development of the Host Plant Root System. Applied and Environmental Microbiology, 3795-3801.
Schwyn B, Neilands JB (1987) Universal Chemical Assay for the Detection and Determination of Siderophores. Analytical Biochemistry 160: 47-56.

Siegmund I, Wagner F (1991) New Method for Detecting Rhamnolipid Excreted by Pseudomonas Species During Growth on Mineral Agar. Biotechnol. Tech. 5 (4): $265-268$.

Smalla K, Wieland G, Buchner A, Zock A, Parzy J, Roskot N, Heuer H, Berg G (2001) Bulk and Rhizosphere Soil Bacterial Communities Studied by Denaturing Gradient Gel Electrophoresis. Plant Dependent Enrichment and Seasonal Shifts. Applied and Environmental Microbiology 67: 4742-4751.

Sorensen J (1997) The Rhizosphere as a Habitat for Soil Microorganisms. In: Van Elsas JD, Trevors JT, Wellington EMH (eds.), Modern Soil Microbiology, Marcel Dekker, Inc., New York, pp. 21-45.

Vestberg M, Kukkonen S, Saari K, Parikka P, Huttunen J, Tainio L, Devos N, Weekers F, Kevers C, Thonart P, Lemoine MC, Cordiwe C, Alabouvette C, Gianinazzi S (2004) Microbial Inoculation for Improving the Growth and Health of Micropropagated Strawberry. Applied Soil Ecology 27: 243-258. 
